\title{
Economy and Pollution by CO2 Emissions - Kuznets Environmental Curve in Asia Pacific Countries
}

\section{Carlos Francisco Ortiz-Paniagua ( $\nabla$ carlos.ortiz@umich.mx )}

Institute of Economic and Business Research from State University of Michoacan

\section{Mario Nuno Mata}

Polytechnic Institute of Santarém

\section{Mario Gómes}

Institute of Economic and Business Research from State University of Michoacan

José Moleiro Martins

Instituto Politécnico de Lisboa

Juan González-Garcia

Economics Faculty from State University of Colima

Rui Miguel Dantas

Instituto Politécnico de Lisboa

\section{Research Article}

Keywords: Economy, Economic Growth, CO2 Emissions, Kuznets Curve, Asia Pacific

Posted Date: May 18th, 2021

DOl: https://doi.org/10.21203/rs.3.rs-434217/v1

License: (c) (i) This work is licensed under a Creative Commons Attribution 4.0 International License.

Read Full License 


\title{
Economy and Pollution by CO2 Emissions - Kuznets Environmental Curve in Asia Pacific Countries
}

Carlos Francisco Ortiz-Paniagua ${ }^{1+}$, Mário Nuno Mata $^{45+}$, Mario Gómez ${ }^{2+}$, José Moleiro Martins $^{46+}$, Juan González-García ${ }^{3+}$, Rui Miguel Dantas ${ }^{4+}$

${ }^{1}$ Institute of Economic and Business Research from State University of Michoacan (Universidad Michoacana de San Nicolás de Hidalgo) carlos.ortiz@umich.mx. ORCID: https://orcid.org/0000-0003-3645-1527.

${ }^{2}$ Institute of Economic and Business Research from State University of Michoacan (Universidad Michoacana de San Nicolás de Hidalgo) mgomez@umich.mx. ORCID: https://orcid.org/0000-0002-4906-0966.

${ }^{3}$ Economics Faculty from State University of Colima (Universidad de Colima) joggar@ucol.mx.

${ }^{4}$ ISCAL-Instituto Superior de Contabilidade e Administração de Lisboa, Instituto Politécnico de Lisboa; rmdantas@iscal.ipl.pt

${ }^{5}$ Polytechnic Institute of Santarém, School of Management and Technology (ESGTS-IPS) mnmata@iscal.ipl.pt

${ }^{6}$ Instituto Universitário de Lisboa (ISCTE-IUL), Business Research Unit (BRUIUL), zdmmartins@gmail.com

These authors contributed equally to this work

\begin{abstract}
The economies of the Asia Pacific region (APEC) are among the most dynamic, with the highest levels of commercial activity and environmental degradation in the world. One way to study trends in the relationship between the economy and pollution is the Environmental Kuznets Curve (EKC). This perspective assumed that in the long-term, higher levels of wealth would be achieve lower pollution levels. The aim was analyze whether the EKC behavior occurs for the APEC economies. The method used was an econometric model for carbon dioxide (CO2) emissions and GDP. The results showed stationary unit root in first differences, this suggest the presence of EKC behavior was explained with a high

probability level that the GDP coefficient would reach an inflection point to become negative and significant.
\end{abstract}

Keywords:

Economy, Economic Growth, CO2 Emissions, Kuznets Curve, Asia Pacific 


\section{Introduction}

The Asia Pacific region is better understood, if one considers that the economies of the 21 countries that make up the Asia Pacific Cooperation Forum (APEC) are found in it which cover $47 \%$ of international trade; represents $39 \%$ of the world's population and contributes around $60 \%$ of GDP, (APEC, 2019). This explains why the economies of this region have registered sustained economic growth for more than 20 years (World Bank 2019).

Economic growth has come at the expense primary goods consumption, natural resources and the deterioration of the environment. The region is one of those that generate the largest ecological footprint of the planet, consumption of resources over the bio-capacity to regenerate them, in Wakernagel and Ress, (1998) concept. The ecological footprint of the countries located in the Pacific Basin predominantly exceeds their bio-capacity, that is, they have ecological debt, (Footprintnetwork 2021; Wackernagel \& Rees 1998).

This situation has led to concern about environmental deterioration, considering several sections on ecological, environmental and energy aspects as challenges that humanity will face in the coming years, in the Millennium Development Goals (Motala, et al. 2015). In such a way that one of the great planetary challenges; sustainable development; Recognized at the Rio Summit (Cumbre de Rio) since 1992, almost five decades after its completion, it still maintains as one of the pending subjects of humanity, the reduction of environmental deterioration.

In this way, a boost in environmental protection policies is to be expected, even in commercial and economical aspects. However, the economic integration policies of APEC have focused in aspects such as: cooperation, tariff reduction, education, science and technology, new communication technologies development, among other items. The integration has been in economic, commercial and investment terms, remaining a perspective of domination of large economies such as China in Asia and North America (Hernández 2013).

Then, environmental policy is still a secondary issue in APEC integration agenda, however the last years of twenty century, were included declarations against environmental deterioration, as an example some APEC countries have suggested lists and classifications 
for environmental goods in the non-agricultural market access negotiation group, identifying more than 109 products to be considered in the trade liberalization agreement, emphasizing in environmental goods according to their end use (Martínez, 2006).

The main concern of APEC's economic integration was economic growth from a neoclassical paradigm, which relies on technological innovation to reduce long-term negative environmental impacts and maintain growth rates (Guilló \& Magalhaes 2018). But what has been environmental pollution consequences? Or How have long-term economic growth and environmental impact behaved in APEC countries? Considering GDP and CO2 emissions (per inhabitant) as an approximation to these variables and taking as a reference the Environmental Kuznets Curve (EKC).

There is an implicit idea in the EKC model that economic development is a process that progresses in phases to consolidate itself. An initial stage development and environmental degradation are incipient. Second phase of development is accompanied by high rates of environmental degradation. In a third stage, as economic processes incorporate technological improvements, materials substitution and greater social demands, they will promote changes in the laws and environmental management, with which the environmental impact would tend to decrease with increases in incomes and development.

The aim of present is to verify the trend in the behavior and interaction between the variables GDP and carbon dioxide (CO2), per inhabitant in APEC countries. To achieve the aim, the article is organized into five sections. The first describes the relationship between economy, development and environmental quality, discussing the theoretical positions, relevant background work for the study in the countries of the Pacific Basin. The third part describes the econometric techniques, for the fourth part to describe the results, discuss them and finally the conclusions are presented.

\section{Theoretical aspects of EKC}

The relationship between the economy and the environment has been emphasized since the 1970s. After the Club of Rome declared that the greatest challenges for humanity in the last quarter of a century would be: 1) degradation of natural resources in quality and quantity; 
2) increased demand for energy, supplies and food; and 3) an increase in income inequality, (Meadows, et al. 1972 y Mesarovic and Pestel, 1975).

This assumes that greater economic growth leads to greater development which in turn modifies the economic structure. The EKC implies that a low-income economy (incipient agricultural and industrial sectors) has low impacts on environmental quality. In a second phase, more developed agriculture and industry generate a higher level of wealth and cause further deterioration in environmental quality. Then, in a third stage, policies are implemented to improve environmental quality and economic structure changes, to be based on more efficient and less polluting technologies and increase relative participation of services sector in GDP. (Selden 1994; Dasgupta, Laplante, Wang \& Wheeler 2002; Deacon \& Norman 2004; Cantos, et al. 2011; Balsalobre et al 2016 \& Catalán 2014).

Other evidences show that innovations also generate new sources of pollution, replicating the behavior of the EKC, with different growth rates starting a new initial stage, can show an inverted $\mathrm{N}$ form between income level and environmental quality, due to energy regulation delays technological obsolescence. Some studies have obtained evidence of the pattern described by the relationship between air pollution and production levels, in which, despite finding the relationship described, per inhabitant, the global emission of pollutants will continue to increase. (Selden, 1994; Dasgupta, Laplante, Wang, y Wheeler, 2002; Balsalobre, et al 2017).

A decisive factor in the analysis of the $\mathrm{EKC}$ is the income elasticity in relation to $\mathrm{CO} 2$ emissions, which implies that reaching the determined level of income would produce changes in the preferences of consumers who would be willing to spend a greater proportion of their income. income in environmental quality, as if it were a luxury good (Baldwin, 1995; Selden \& Song, 1994).

Some less optimistic working papers highlighted that empirical repercussions could approach to theoretical aspects to EKC, without significant repercussions on economic policy, Stern (2004), Selden \& Song (1994) y Wagner (2008). It is argued that the behavior of the EKC, despite finding the expected ratio per inhabitant, indicates that the global emission of pollutants will continue to increase (Selden \& Song, 1994). 
There is skepticism of both theoretical and empirical works, for the proposition of a simple and predictable relationship between pollution and per capita income. However, there may be an inverted $U$ shape in relation to urban environmental concentrations of some pollutants and income, although this should be more rigorously tested in time series or panel data methods (Stern 2004). On the other hand, other authors comment that the studies referring to EKC are wide and varied, at the same time that they have had applications in severals economies of the world, despite being such a widespread analysis with econometric tools, but they might not be adequate, since they can lead to contradictory conclusions (Wagner, 2008). Alternatively, some studies propose the use of non-parametric techniques such as polynomial splines, which are presented as an alternative method when decomposing the time series and examine the EKC using confidence bands and simulations (Wang, 2011).

A study for 182 countries, applying panel data and cross section, found EKC hypothesis is acceptable in both approaches, although inflection points in the cross sections are not entirely reliable. It is also highlighting the importance of adequately addressing problems such as heterogeneity, structural changes and spatial interaction and the issue of causality was not reviewed (Atwi, Barberán, Mur \& Angulo, 2018).

Particularly for some countries in APEC, studies can be seen that demonstrate the EKC with different methodological approaches, which are shown in Table 1. Although it is a highly studied hypothesis for different countries and regions of the world, the techniques and variables used give an important diversity to the analyzes. 
Table 1. EKC some studies in APEC Countries

\begin{tabular}{|c|c|c|c|c|c|c|}
\hline Authors & Year & Countries & Variables & Methodological approach & $\begin{array}{c}\text { EKC is } \\
\text { tested }\end{array}$ & Considerations \\
\hline $\begin{array}{l}\text { Brajer, } \\
\text { Mead y } \\
\text { Xiao }\end{array}$ & 2011 & China & $\begin{array}{l}\text { SO2, TSP, NO2, Income, Pupulation Density, } \\
\text { North Location, Coast Location }\end{array}$ & Nemerrow Methodology & YES & $\begin{array}{l}\text { Individual analysis of pollutants with an inverted U EKC behavior. } \\
\text { However, when the indices are analyzed as a whole, an N shape } \\
\text { appears to occur, which raises a worrying picture of an increase in } \\
\text { health costs derived from pollution. }\end{array}$ \\
\hline $\begin{array}{l}\text { Dong, Sun, } \\
\text { Li \& Liao }\end{array}$ & 2018 & $\begin{array}{l}14 \text { APEC } \\
\text { Countries }\end{array}$ & Natural Gas Consumption and $\mathrm{CO} 2$ Emissions & $\begin{array}{c}\text { Panel Data, Granger } \\
\text { Causality, Cointegration, } \\
\text { Dependence Analisys of } \\
\text { Cross Section, AMG y } \\
\text { FMOLS. } \\
\end{array}$ & YES & $\begin{array}{l}\text { Test EKC, in } 13 \text { of the } 14 \text { countries independently of GDP per } \\
\text { capita. Furthermore, the EKC hypothesis is presented independently } \\
\text { of income levels. }\end{array}$ \\
\hline $\begin{array}{l}\text { Jalil y } \\
\text { Mahmud }\end{array}$ & 2009 & China & GDP, GDP^2, CO2 y Energy Consumption & $\begin{array}{l}\text { Autoregressive with } \\
\text { Distributed Lags, Granger } \\
\text { Causality and Unit Root. }\end{array}$ & YES & $\begin{array}{l}\text { Energy consumption is significant in explaining } \mathrm{CO} 2 \text { emissions. } \\
\text { GDP squared and } \mathrm{CO} 2 \text { has negative sign. }\end{array}$ \\
\hline $\begin{array}{l}\text { Fong, } \\
\text { Salvo y } \\
\text { Taylor }\end{array}$ & 2020 & $\begin{array}{l}\text { Southeast } \\
\text { Asian }\end{array}$ & $\begin{array}{l}\text { Nox, SO2, PM2.5, Urbanization, Renewable } \\
\text { Energy Consumption, Energy intensity per unit } \\
\text { of GDP, Foreign Direct Investment as percent } \\
\text { of GDP and participation of the Services Sector }\end{array}$ & Spatial Econometrics & YES & $\begin{array}{c}\text { The EKC is tested for three contaminants. There is a significant } \\
\text { difference in the inflection point for low-income and high-income } \\
\text { countries. }\end{array}$ \\
\hline $\begin{array}{l}\text { Al-Mulai, } \\
\text { Saboori y } \\
\text { Ozturk } \\
\end{array}$ & 2015 & Vietnam & $\begin{array}{l}\text { Electricity consumption (renewable and fossil } \\
\text { sources), GDP, CO2, Labor Force, Exports, } \\
\text { Imports and Capital. }\end{array}$ & $\begin{array}{c}\text { Autoregressive with } \\
\text { Distributed Lags, Granger } \\
\text { Causality and Unit Root }\end{array}$ & NOT & $\begin{array}{l}\text { The consumption of renewable energy has not been significant in } \\
\text { reducing pollution. The short-term relationship between pollution } \\
\text { and GDP is positive.. }\end{array}$ \\
\hline $\begin{array}{l}\text { Wen- } \\
\text { Cheng Lu }\end{array}$ & 2017 & $\begin{array}{l}16 \text { Asian } \\
\text { Countries }\end{array}$ & Energy consumption, $\mathrm{CO} 2, \mathrm{GDP}$ y GDP^2 & $\begin{array}{l}\text { Panel Data, Granger } \\
\text { Causality, Cointegration, } \\
\text { Dependence Analisys of } \\
\text { Cross Section }\end{array}$ & Partially & $\begin{array}{l}\text { There is regional heterogeneity in the EKC hypothesis. Energy use } \\
\text { is an important determinant of GHG emissions. The results, (except } \\
\text { for Southeast Asia), indicate that the environment degrades as } \\
\text { income increases, until the threshold is reached. }\end{array}$ \\
\hline $\begin{array}{l}\text { Navarrete, } \\
\text { et al. }\end{array}$ & 2009 & México & $\mathrm{CO} 2, \mathrm{GDP}$ y GDP^2 & $\begin{array}{c}\text { Granger Causality and Unit } \\
\text { Root }\end{array}$ & NOT & $\begin{array}{l}\text { It is necessary to expand the transmission mechanisms between the } \\
\text { variables }\end{array}$ \\
\hline
\end{tabular}


The studies presented in Table 1 are just some studies for the region in the last decade, it can be seen that the use of macroeconomic variables such as the emission of Greenhouse Gases (GHG), (mainly CO2), the GDP, GDP^2 and Renewable Energy Consumption. It is emphasized that the work of Al-Mulai, Saboori and Ozturk (2015) CAK is not demonstrated, whereas it is only partially demonstrated for 16 Asian countries (WenCheng, 2017), because that non-fossil energy consumption was decisive, an aspect related to energy supply policies.

According to the above, there are different arguments for and against the validation of the EKC hypothesis, so it is important to continue generating empirical evidence that contributes to the generation of knowledge that provides elements on the relationship between economic activity and environmental quality.

From a reflective perspective EKC approaches contain arguments that serve as theoretical support for the hypothesis, but that are not largely operative in the economic, social and institutional circumstances in developing countries. In particular, inequality in income distribution and the fragility of the institutional framework in environmental matters weaken the main foundations that support this hypothesis, making it less important to wait and grow to achieve improvements in environmental quality (Zilio, 2012).

Although conclusive results are not presented, however, most studies show similar trends. While it is worth noting that the variants and the assumptions of the models have differences, which influence the results obtained. The EKC continues to be a reference for interpreting relationship and behavior between environmental quality, economic growth and development styles. With analysis, EKC could be show phenomena such as technology advanced, structural composition of GDP, environmental regulations and social preferences. But is necessary to know the context and other issues about the countries to study.

\section{The theoretical model of the Environmental Kuznets Curve}


It is possible to define a parametric form of the EKC hypothesis defined as the relationship between $\mathrm{CO} 2$ pollutant emissions and income per inhabitant, it can be described in a model as follows:

$$
\begin{gathered}
E_{i t}=A_{E i}+\alpha_{1} Y_{i t}+\alpha_{2} Y_{i t}^{2}+\mu_{i}(1) \\
(\mathrm{i}=1,2, \ldots \mathrm{n} ; \mathrm{t}=1,2, \ldots, \mathrm{tn})
\end{gathered}
$$

For $E_{i t}$ observations corresponding to each APEC countries $i$ and $t$ indicates year, AEi are fixed effects or unobserved heterogeneity; and $\mu$ is the error term. $E$ are pollutant emissions, per capita in metric tons, $Y$ is logarithm of income per inhabitant and $Y^{2}$ square this variable. In both cases $\alpha$ represents the degree of response of $E_{i t}$, income elasticity; $\mu$ the stochastic error decomposes into: $\mu_{i t}=\mu_{i}+\delta_{t}+\varepsilon_{i t}$. [2]. In which $\mu_{i}$ are the unobservable effects, $\delta_{t}$ are the non-quantifiable effects that change over time, although not between countries, finally, $\varepsilon_{i t}$ denotes randomness.

A disadvantage of this model is that it is not clear what kind of interpretation to give to the estimated coefficients. However, seven different behaviors of the relationship between $E_{i t} \mathrm{y}$ GDP per capita (Balsalobre, et al. 2016).

\subsection{Empirical model}

Starting from equation [1], the effect of the income level on $\mathrm{CO} 2$ has been estimated using an autoregressive panel data cointegration model, with distributed lags. The expression takes the following form:

$$
\begin{gathered}
E_{i t}=\alpha_{E i}+\beta_{1} Y_{i t}+\beta_{1} Y_{i, t}^{2}+\delta_{1} E_{i, t-1}+\delta_{1} Y_{i, t-1}+\delta_{2} Y_{i, t-1}^{2}+\varepsilon_{i t} \\
(\mathrm{i}=1,2, \ldots, \mathrm{N} ; \mathrm{t}=1,2, \ldots, \mathrm{T})
\end{gathered}
$$

$E$ are pollutant emissions, per capita in metric tons, $Y$ is logarithm of income per inhabitant and $Y^{2}$ square this variable. In both cases $\alpha$ represents the degree of response of $E_{i t} ; \mu$ is the error term, which in turn decomposes into: $\mu_{i t}=\mu_{i}+\delta_{t}+\varepsilon_{i t}$. (2). Which $\mu_{i}$ are the unobservable effects, $\delta_{t}$ there were the non-quantifiable effects that change over time, with a lag for the variable Y, although not so between countries, finally, $\varepsilon_{i t}$, the random error term. 
For this model, the influence of per capita income on environmental pressure (increase in CO2) would be explicit in the estimate. However, seven different behaviors of the relationship between $E_{i t}$ and GDP. Where $\alpha_{E i}$ are the fixed effects or unobserved heterogeneity and $\varepsilon$ is the error term, GDP is a non-stationary variable. Fundamental statistical tests have been used to determine the order of integration of the variables.

If the variables are cointegrated they tend to move together maintaining a long-term equilibrium, that is, a stationary relationship between variables, the cointegration between variables implies, according to the Granger representation theorem, (Granger 1998) that the system admits a representation in the form of error correction mechanism (Engle \& Granger, 1987). For this reason, instead of estimating equation [3], its parametric transformation has been used:

$$
\Delta E_{i t}=\alpha_{E i}+\beta_{1} \Delta Y_{i t}+\beta_{2} \Delta Y_{i, t}^{2}+\left(\delta_{0}-1\right)\left[E_{i, t-1}+\frac{\delta_{1}+\beta_{1}}{\delta_{0}-1} Y_{i, t-1}+\frac{\delta_{2}+\beta_{2}}{\delta_{0}-1} Y_{i, t-1}^{2}\right]+\varepsilon_{i t}
$$

A model is established with an error correction mechanism, all the variables are expressed in differences and there is a term that collects the adjustment of the deviations of the dependent variable with respect to its long-term equilibrium value. The existence of an error correction mechanism representation is not subject to the most common problems of a regression, (given the cointegration) since all the variables that enter the equation are stationary.

The test of the cointegration between emissions, income and income squared can be performed using the two-stage method of Engle and Granger. First, we must perform the regression in levels by ordinary least squares (OLS) and collect the residuals of the estimate. Second, we estimate the equation [4], OLS, where the error correction mechanism includes the residuals of the previously estimated equation instead of the terms in levels of the variables that enter it.

If the parameter associated with the error correction mechanism, using the residuals of the cointegration equation, is statistically significant " $t$ " it can be stated, according to the Granger representation theorem, that the series are cointegrated (Granger 1998). The evidence in favor of the EKC requires that the coefficient $\beta_{1}$ is positive and the coefficient 
$\beta_{2}$ is negative, since in this way a quadratic relationship in the shape an inverted $U$ is obtained. 


\section{EKC applied in APEC Contries}

The behavior of the variables GDP and CO2, per inhabitant, maintains a behavior with variable growth rates throughout the more than five decades shown in Figure 1. It can be highlighted that in terms of graphic representation, $\mathrm{CO} 2$ emissions are more stable than GDP, that is; less variation in growth rates. In the same sense, GDP increases to a greater extent, which suggests the CAK curve, however a reduction in $\mathrm{CO} 2$ emissions has not yet been noticed.

Figure 1. Performance of GDP and CO2 (both per capita) in APEC economies, 1960-2013 (Data in logarithms)

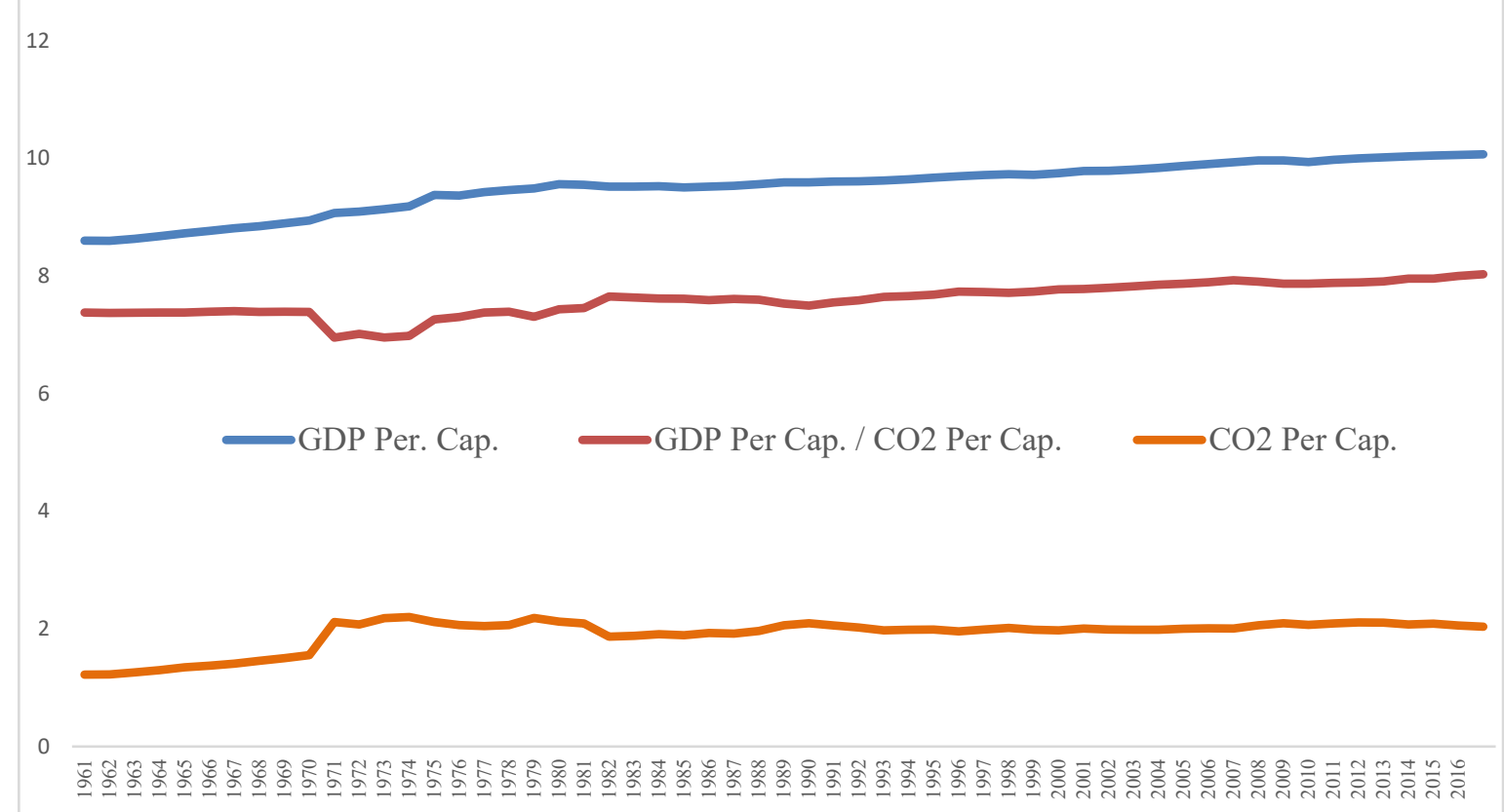

Source: data from World Bank, 2021.

Regarding the relationship between GDP and CO2 per inhabitant for the countries of the Asia Pacific region, it is observed that the behavior of the relationship between the variables adjusts to a quadratic form between 2000 and 2006. Pollutant emissions per unit of However, as of 2007, the rising trend of emissions begins as GDP grows (both per inhabitant). 
Figure 2. GDP and CO2 (both per capita) average for APEC countries (1960-2016).

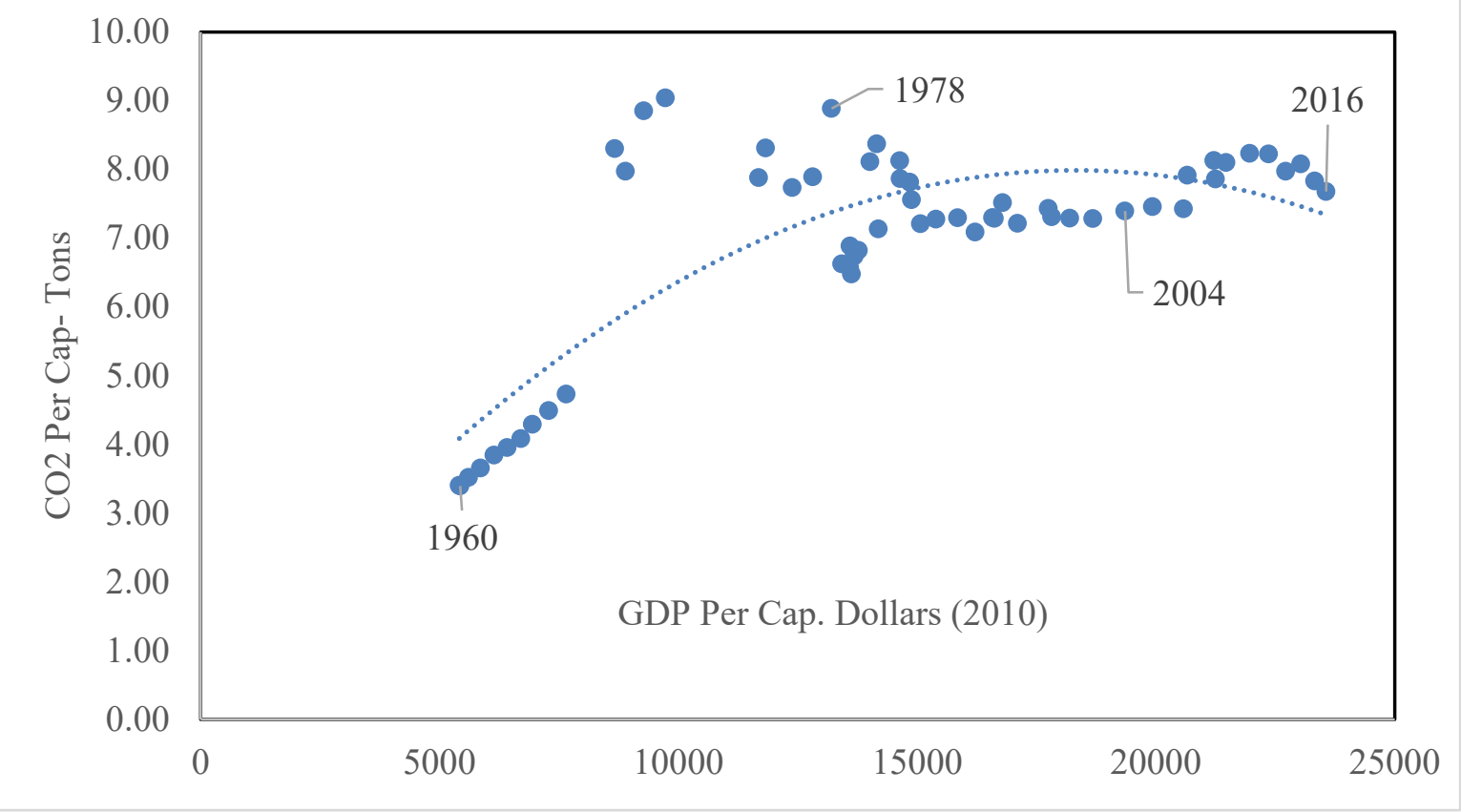

Source: data from World Bank, 2021.

Figure 3. GDP and CO2 (Both Per Cap) in APEC Economies

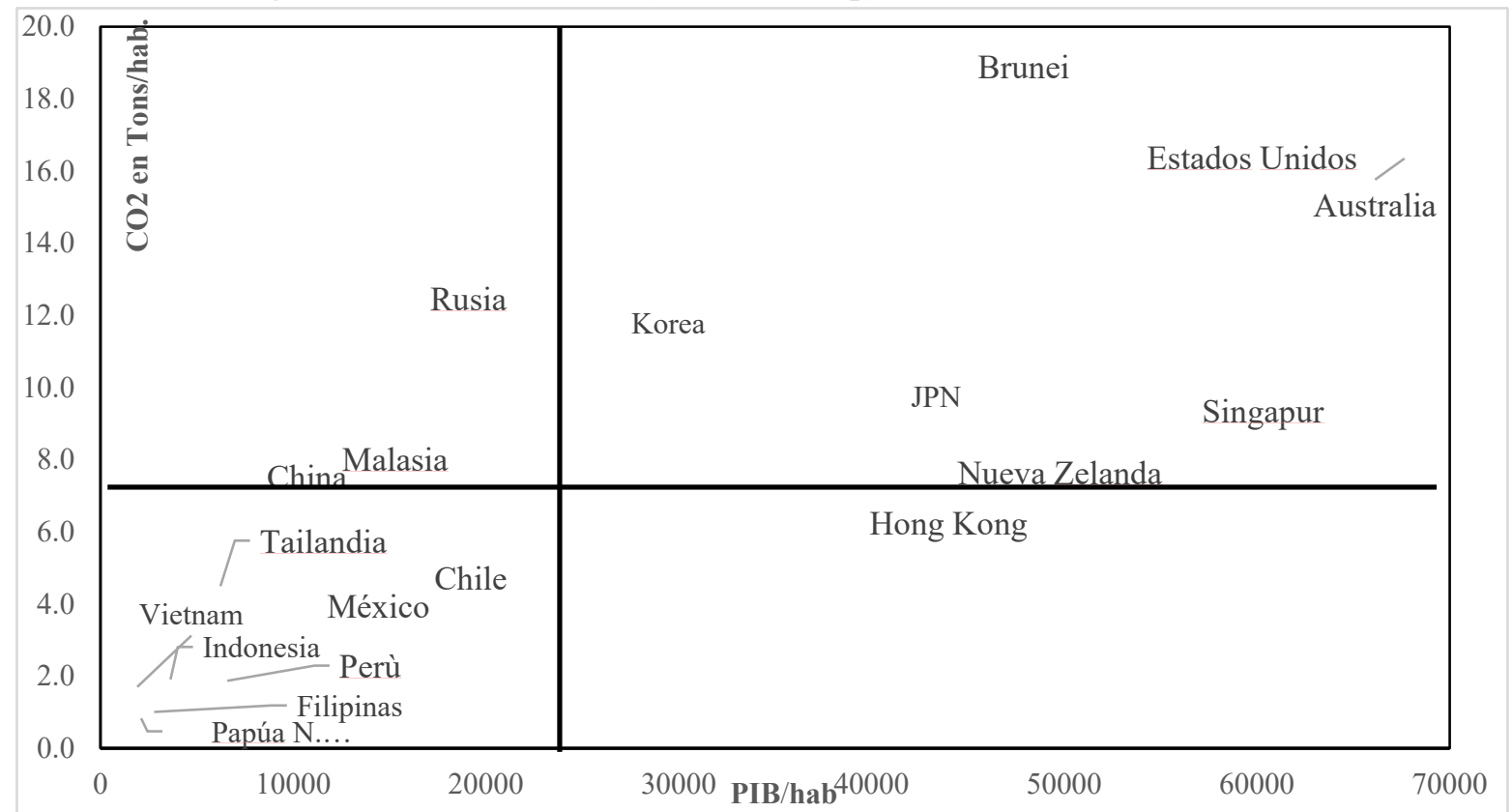

Source: data from World Bank, 2021.

Regarding the behavior, it can be seen that among the countries of APEC, the relationship between per capita GDP and CO2 emissions is heterogeneous, as can be seen in Figures 2 and 3. From an analysis of Quadrants (Figure 3), taking as a reference the averages (7.6 
tons / inhab and 23,713 dollars / inhab.), the countries that show a high CO2 emission accompanied by high levels of per capita GDP: Brunei, Australia and the United States; followed by Singapore, Japan, New Zealand and South Korea. These last four show a notable difference in the level of emissions, with respect to the first three countries.

Hong Kong was located below the average pollutant emissions, but above the average per capita GDP, with greater efficiency in terms of polluting units per unit of GDP / capita. Malaysia and China emit slightly more pollutants with a GDP / inhabitant below the average, unlike Russia whose emissions are above the average. Finally, the countries that have emissions and GDP / inhabitant below the average are: Papua New Guinea, the Philippines, Indonesia, Peru, Vietnam, Mexico, Chile and Thailand (Figure 3).

\section{1. Econometrical analysis CO2 and PIB (per capita) $\left(E_{i t}=A_{E i}+\alpha_{1} Y_{i t}+\alpha_{2} Y_{i t}^{2}+\mu_{i}\right)$.}

In the analysis of time series variables, it is important to know the order of integration and verify if there is cointegration between the variables, to avoid obtaining spurious results. The econometric literature suggests that unit root tests on panel data have greater power than time series unit root tests. According to Baltagi (1995), when combining the time series with the cross-sectional data, there is a greater number of observations, more degrees of freedom, more variability, less collinearity and greater efficiency. However, it is important to first apply some cross-section dependency test before unit root tests with panel data (Pesaran, 2007).

Table 2. Pesaran cross-section dependency test, 2004.

\begin{tabular}{|l|c|c|c|}
\hline Variable & CO2 & PIB & $\begin{array}{c}\text { PIB } \\
\text { Cuadrado }\end{array}$ \\
\hline CD statistic & $55.417 * * *$ & $83.432 * * *$ & $83.493 * * *$ \\
\hline P value & 0.000 & 0.000 & 0.000 \\
\hline
\end{tabular}

Note: $* * *$ denotes rejection of the null hypothesis at $1 \%$ significance.

Source: data from World Bank, 2021.

Table 2 shows the results of the cross-section dependency CD test. For all variables, the null hypothesis of non-dependence of cross section is rejected at $1 \%$ of significance. Therefore, there is cross-sectional dependence for all variables, that is, the GDP (per inhabitant) and $\mathrm{CO} 2$ (per inhabitant) of each country are correlated with each other. 
According to these results, traditional or first-generation tests such as the Levin, Lin \& Chu (2002, LLC), Im, Pesaran and Shin (2003, IPS) tests, Fisher's test using ADF (ADF-Fisher) and PP (PP-Fisher) (Maddala \& Wu (1999) \& Choi (2001) would not be adequate. It is very important to apply unit root tests that generate consistent results in the absence of independence and heterogeneity in all panel countries (Riti, Song, Shu \& Kamah 2017), for this, two tests were applied (Pesaran 2007).

Table 3. Unit Root Test

\begin{tabular}{|c|c|c|c|}
\hline Variables & Parameters & CADF & CIPS \\
\hline CO2 & $\mathrm{CT}$ & -0.496 & -1.863 \\
GDP & $\mathrm{CT}$ & -0.252 & -2.009 \\
\hline $\mathrm{GDP}^{\wedge} 2$ & $\mathrm{CT}$ & 1.112 & -1.930 \\
$\begin{array}{c}\text { First difference } \\
\Delta \mathrm{CO} 2\end{array}$ & $\mathrm{C}$ & $-16.070 * * *$ & $-5.449 * * *$ \\
\hline$\Delta \mathrm{PIB}$ & $\mathrm{C}$ & $-13.710^{* * *}$ & $-5.867 * * *$ \\
\hline$\Delta \mathrm{PIB}$ cuadrado & $\mathrm{C}$ & $-13.326 * * *$ & $-5.354 * *$ \\
\hline
\end{tabular}

Note 1: The tests used were: Augmented Dickey Fuller Cross Section (CADF) and Im, Pesaran \& Shin (2003) and Cross Section (CIPS) Pesaran (2007).

Note 2: *** denotes the rejection of the null hypothesis at the $1 \%$ level of significance, $* * 5 \%$ level of significance. C denotes constant and CT denotes constant and trend.

Table 3 shows the results of the new unit root tests with panel data that are consistent in the presence of dependency on the cross sections. The evidence indicates that the variables present unit roots in levels, but are stationary when taking the first difference at a significance level of $1 \%$. To test the presence of an equilibrium or long-term relationship between the integrated variables of the same order, in this research two cointegration tests with panel data are used: the Pedroni (2004) and Fisher tests proposed by Maddala and Wu (1999).

Table 4. Results of the Pedroni cointegration test

\begin{tabular}{|l|c|c|}
\hline Test & Statistical & Prob. Value \\
\hline Panel v & $3.043 * * *$ & 0.001 \\
Panel rho & $-4.293 * * *$ & 0.000 \\
\hline Panel PP & $-5.086 * * *$ & 0.000 \\
Panel ADF & $-3.647 * *$ & 0.000 \\
Group rho & -0.807 & 0.209 \\
Group PP & $-3.387 * * *$ & 0.000 \\
Group ADF & $-2.464 * * *$ & 0.006 \\
\hline
\end{tabular}


Note: $* * *$ and $* *$ denote rejection of the null hypothesis of no cointegration at $1 \%$, and $5 \%$ significance, respectively.

In the results of the Pedroni test shown in Table 4, the null hypothesis of no cointegration is rejected for most of the statistics with a significance level of $1 \%$. This is confirmed by the results of the Kao and Fisher tests (Tables 5 and 6). In the case of Fisher's test, it is indicated that at least two cointegration relationships exist between the analyzed variables, that is, there is a long-term equilibrium relationship between the three variables; CO2, GDP and GDP2 (Table 4).

Table 5. Kao cointegration test

\begin{tabular}{|l|c|}
\hline Test & t-Statistic \\
\hline ADF & $-4.678 * * *$ \\
P-value & $(0.000)$ \\
\hline
\end{tabular}

Note: $* * *$ The null hypothesis is rejected at $1 \%$.

Table 6. Fisher cointegration test

\begin{tabular}{|c|c|c|c|c|}
\hline Hypothesis & Fisher statistics* & & Fisher statistics * & \\
\hline CE(s) number & (Trace test) & Prob. & $\begin{array}{c}\text { (Maximum eigenvalue } \\
\text { test) }\end{array}$ & Prob. \\
\hline Ninguno & 173.20 & 0.000 & 144.50 & 0.0000 \\
\hline Al menos 1 & 66.55 & 0.002 & 55.03 & 0.036 \\
\hline Al menos 2 & 57.58 & 0.021 & 57.58 & 0.021 \\
\hline
\end{tabular}

Note: * denotes rejection of the null hypothesis of no cointegration at $1 \%$ significance.

The most common Least Ordinary Tables (OLS) technique to estimate the coefficients of panel data models turns out to be biased and produces inconsistent estimates when the variables are cointegrated. Recently, new methods have been developed to estimate cointegration relationships using panel data such as Fully Modified OLS (FMOLS) and Dynamic OLS (DOLS) estimators (Phillips \& Moon 1999; Pedroni 2001a; Kao \& Chiang 2001).

These approximations produce coefficient estimators that are asymptotically unbiased and normally distributed (Pedroni 2001b; Kao \& Chiang, 2001). Pedroni (2001b) argues that the FMOLS estimator behaves relatively well and, even in small samples, generates consistent estimates and allows controlling the endogeneity of its regressors and the serial correlation. Due to the above, in this research both FMOLS and DOLS estimators will be used for heterogeneous cointegrated panels (Pedroni, 2001b: 117 and 118). 
Table 7. Long-term estimation with DOLS and FMOLS

\begin{tabular}{|l|r|r|}
\hline Variable & \multicolumn{1}{|c|}{$\begin{array}{c}\text { DOLS } \\
\text { Coefficients }\end{array}$} & \multicolumn{1}{c|}{$\begin{array}{c}\text { FMOLS } \\
\text { Coefficients }\end{array}$} \\
\hline GDP & $1.367^{* * *}$ & $1.541^{* * *}$ \\
GDP 2 & $-0.061^{* * *}$ & $-0.073^{* * *}$ \\
\hline
\end{tabular}

Note: $* * *, * *$ and $*$ denote rejection of the null hypothesis of no cointegration at 1,5 and $10 \%$ significance, respectively.

According to Table 7, with the FMOLS and DOLS estimators all the variables are statistically significant. The long-term elasticity of per capita GDP is positive, which implies that as economic activity increases, carbon dioxide emissions also increase. Furthermore, the hypothesis of the environmental Kuznets curve is supported by the results for these countries, since the coefficient of GDP is positive and that of GDP squared is negative, both statistically significant at $1 \%$.

Table 8. Short-term and long-term causality results.

\begin{tabular}{|l|c|c|c|c|}
\hline Variables & \multirow{2}{*}{$\Delta \mathbf{C O 2}$} & \multirow{2}{*}{$\mathbf{G D P}$} & Short term & long term \\
\cline { 4 - 5 } & --- & $0.491^{* * *}$ & $-0.024^{* * *}$ & $-0.035^{* * *}$ \\
\hline$\Delta$ CO2 & 0.037 & --- & -0.012 & 0.014 \\
\hline$\Delta$ PIB & 0.150 & 0.879 & --- & 0.212 \\
\hline
\end{tabular}

Note: $* * * * *$, and $*$ denote statistical significance at the 1,5 , and $10 \%$ level, respectively.

According to Tables 7 and 8 , the results show that the causal relationship goes from economic activity to emissions in the long term at a significance level of $1 \%$. These results are also confirmed in the short term, there is a unidirectional causal relationship that goes from economic activity to polluting emissions. The above can be interpreted as that economic activity contains important information that helps to better predict the behavior of emissions.

\section{Discussion of results.}

The econometric tests implemented to check if the CAK shows a quadratic trend for the variables GDP and $\mathrm{CO} 2$. In other words, the hypothesis of the relationship between 
economic growth and environmental quality, measured from carbon dioxide emissions, (both variables relativized per inhabitant) per unit of product is confirmed. Therefore, it can be affirmed that, in the long term, pollutant emissions per unit of production maintain a tendency to grow to a lesser extent than the growth of the economy. This situation would suggest that productivity is moving towards a trend of less negative environmental impact, with regard to $\mathrm{CO} 2$ pollution. The implications this has would be a function of the degree of technological development and the prevailing economic structure in APEC.

Although they have reduced emissions per unit produced, it must be taken into account that pollution as a whole is greater, since the wealth generated or GDP is also greater, although more efficient, in absolute terms it continues to grow; going from 44 to 145 (kilotonnes) of $\mathrm{CO} 2$ emissions, for the main countries of the Asia Pacific region, during the period 1960-2013. On average per inhabitant, it went from 2.4 to 7.6 tons per inhabitant. Meanwhile, the GDP / inhabitant has grown from 574 dollars to 23.7 thousand dollars. In both cases, the standard deviation is important: 5.5 tons for the first and 21 thousand for the second; This reflects the existing differences in the levels of economic development in the Asia-Pacific region.

The difference in the increases between the two variables suggests that the Asia Pacific countries are improving aspects such as regulatory frameworks and technologies, although there is still a heterogeneous rate. CO2 emissions per unit of GDP / inhab, are increasingly efficient, which can be attributed to technological innovation, as well as increasingly rigid regulations, it is also appreciated that this relationship is relatively slow, so that It would be necessary for innovations to be more frequent, of greater scope for their diffusion and above all of greater impact. In the analysis of Figure 4, it shows that the trend in a comparison between countries for the year 2013 is growing and positive, that is; the higher the GDP, the higher the polluting emissions.

The productive structure of the economies analyzed has a close and determining relationship in terms of the behavior of the relationship between the variables analyzed. That may be the situation that Hong Kong has very low emissions and high-income levels, given that its productive structure is predominantly tertiary, focused on activities mainly of an administrative and financial nature. 
The revised EKC and under the statistical tests applied to the available information, reaches results similar to those found by Vergara, Maza and Quezada, (2018) for Latin America, confirming the relationship for seven countries, including Mexico, Brazil and Chile. (2018: 5). At the same time, there was also a coincidence with the studies by Brajer, Mead \& Xiao, 2011; Dong, Sun, Li \& Liao, 2018; Jalil \&Mahmud, 2009; Fong, Salvo \&Taylor, 2020 and Al-Mulai \& Navarrete, et al. 2009. Whose variables analyzed have slight variations with the present study. However, the long-term trend would be confirmed by different methods and for different analysis periods.

\section{Conclusions}

The formulation of the initial hypothesis on a long-term trend for the economies located in the Asia Pacific region, assumes that a relationship could be found between the variables GDP per inhabitant and $\mathrm{CO} 2$ per inhabitant. The results suggest that the series can cointegrate, so that both have information that allows knowing and predicting their behavior. Although, the assumption that both variables adjust to a U-shaped relationship in the long term, the heterogeneity of the economies analyzed must be taken into account, as well as their productive structures. With the available information, it was possible to corroborate that the analysis of panel data and cross-section for the period analyzed indicates that valid and unbiased information for the EKC was produced.

The importance of the Asia Pacific region lies, among other things, in the growing trade flow in the region driven by the economies of China and the United States. Therefore, it is relevant to identify the terms and conditions adopted by international trade in this macroregion of the planet. In the event that the commercial relationship integrates various aspects such as: environment, flow of people, technology transfer, financing for development in strategic areas of countries with greater backwardness. The information on the way in which development is configured will be transcendent and for this, this article showed the relationship between two key elements for the future commercial relationship: income and polluting emissions. One of the greatest challenges for the region will be precisely to reduce the disparity between the economies in order to continue fostering the commercial expansion of the APEC region. 
One of the elements that remain pending and probably for the next few years will be of vital importance, it will undoubtedly be the energy policy of the countries. In the case of the Asia Pacific region, which at the moment is heterogeneous the use of free sources of fossil fuels, the trend is towards decarbonization and the promotion of renewable and alternative energies (wind, solar, hydroelectric, nuclear and tidal wave, etc.) which is likely to drive a reduction in pollution.

Finally, the growth of GDP per inhabitant has advanced in terms of efficiency, emitting less $\mathrm{CO} 2$ per unit of product, however, in absolute values this is reflected in air pollution of capital magnitudes, this is multiplying emissions by three in a few more than 50 years. However, China and the United States participate with $70 \%$ of the emissions of the APEC region, although adding Russia and Japan the figure grows to $83 \%$ of a sample of APEC region, as well as the wealth generated. In APEC there is a high concentration in few economies that generate the highest proportion of both variables (GDP and CO2). It is because of this situation that these countries should be the ones promoting the use of cleaner technologies and stricter environmental regulations, which will have implications for areas such as trade and regional and world production.

\section{Conflicts of Interest}

The authors declare no conflict of interest. 


\section{References}

Atwi, M., R. B., Mur, Jesús \& Ana Angulo. (2018). CO2 Kuznets curve revisited: from cross-sections to panel data models. Investigaciones regionales: Journal of Regional Research, (40), 169-196

Balsalobre L., D. B. \& Álvarez-Herranz, A. (2016). Economic growth and energy regulation in the environmental Kuznets curve. Environmental Science and Pollution Research, 23(16), 16478-16494.

Balsalobre-Lorente, D., Shahbaz, M., Ponz-Tienda, J. L., \& Cantos-Cantos, J. M. (2017). Energy Innovation in the Environmental Kuznets Curve (EKC): A Theoretical Approach. In Carbon Curva AFootprint and the Industrial Life Cycle (pp. 243-268). Springer, Cham.

Baltagi, B.H. Econometric Analysis of Panel Data, (1995). John Wiley and Sons. New York, USA, B01K2R49OS.

Cantos, J. Balsalobre, D. (2011). Las energías renovables en la curva de kuznets ambiental: una aplicación para España. Estudios de economía aplicada. 2(29): 1 - 32.

Catalán, H. (2014). Curva ambiental de Kuznets: implicaciones para un crecimiento sustentable. Economía Informa, 389. 19-37.

Choi, I. (2001) Unit Root Tests for Panel Data. Journal of Intern. Money and Finance. 20, 249-272. https://doi.org/10.1016/S0261-5606(00)00048-6

Dasgupta, S., Laplante, B., Wang, H., \& Wheeler, D. (2002). Confronting the environmental Kuznets curve. Journal of economic perspectives. 16(1), 147-168.

Engle, R. F., \& Granger, C. W. (1987). Co-integration and error correction: representation, estimation, and testing. Econometrica: journal of the Econometric Society. 251-276.

Falck R., M. (2018). Veinte años navegando el Pacífico, conectando ideas. México y la cuenca del pacífico, 7(19), 9-14. Recuperado en 31 de mayo de 2018, de http://www.scielo.org.mx/scielo.php?script $=$ sci arttext\&pid $=\mathrm{S} 2007$ 53082018000100009\&lng=es\&tlng=es.

Footprintnetwork, (2021). Global Footprint Network. https://data.footprintnetwork.org/\#/ Enero 2021.

Fong, L. S., Salvo, A., \& Taylor, D. (2020). Evidence of the environmental Kuznets curve for atmospheric pollutant emissions in Southeast Asia and implications for sustainable development: A spatial econometric approach. Sustainable Development. 28(5), 1441-1456. 
Granger, C.W.J. (1998). Some recent development in a concept of causality. Journal of Econometrics, 39, 199-211, https://doi.org/10.1016/0304-4076(88)90045-0.

Guilló, M. D. y Magalhaes, M. (2018). Long-run Sustainability in the Green Solow Model. QM\&ET Working Papers 18-2, University of Alicante, D. Quantitative Methods and Economic Theory. Disponible https://web.ua.es/es/dmcte/documentos/qmetwp1802.pdf, consulta agosto de 2018.

Hernández, H. R. (2013). Las políticas de integración económica en el Pacífico asiático y el Pacífico latinoamericano: una perspectiva mexicana. México y la cuenca del pacifico, 2(5), 17-46.

Im, K. S., Pesaran, M. H. \& Shin. (2003). Testing for unit roots in heterogeneous panels, Journal of Econometrics. 115, 53-74. https://doi.org/10.1016/S03044076(03)00092-7

Kao, Ch. \& Chiang, M-H. (2001). On the estimation and inference of a cointegrated regression in panel data. In Badi H. Baltagi, Thomas B. Fomby, R. Carter Hill (ed.) Nonstationary Panels, Panel Cointegration, and Dynamic Panels (Advances in Econometrics), Emerald Group Publishing Limited, 15, 179-222, ISBN: 978-076230-688-6 eISBN: 978-1-84950-065-4.

Levin, A.; Lin, C.-F.; Chu, C.-S. J. (2002). Unit root tests in panel data: Asymptotic and finite-sample properties. Journal of Econometrics, 108, 1-24, https://doi.org/10.1016/S0304-4076(01)00098-7.

Maddala, G. S. \& Wu, S.A. (1999). Comparative Study of Unit Root Tests with Panel Data and a New Simple Test, Oxf. Bull. of Econ. and Stat. 61, 631-652, https://doi.org/10.1111/1468-0084.0610s1631

Martínez, B. D. A. (2006). Retos para la política ambiental: el debate internacional sobre el comercio de bienes y servicios ambientales. Revista Opera. (6), 233-254.

Meadows, D. H., Meadows, D. L., Randers, J., \& Behrens, W. W. (1972). Los límites del crecimiento: informe al Club de Roma sobre el predicamento de la humanidad. Fondo de Cultura Económica, México, D. F.

Mesarovic, M. y Pestel, E. (1975). La humanidad en la encrucijada. Segundo informe del Club de Roma. Fondo de Cultura Económica, México, D. F.

Motala, S., Ngandu, S., Mti, S., Arends, F., Winnaar, L., Khalema, E., ... \& Martin, P. (2015). Millennium development goals: Country report 2015. United Nations Organisation, UN.org. 
Navarrete, M; Brull, M; Torre, A; Gómez, D; Torres, G. (2009). Verificación de la Curva Ambiental de Kuznets: El caso de México. Revista Estudiantil de Economía. 1(1), $37-54$.

Pesaran, M.H. (2004) General Diagnostic Tests for Cross Section Dependence in Panels. CESifo Working Paper Series. 1229, 1-39, https://doi.org/10.17863/CAM.5113

Pesaran, M.H. (2007) A simple panel unit root test in the presence of cross-section dependence. Journal of Applied Econometrics. 22, 265-312, https://onlinelibrary.wiley.com/doi/abs/10.1002/jae.951

Phillips, P.C.B.; Moon, H. (1999). Linear regression limit theory for non-stationary panel data. Econometrica, 67, 1057-1111, https://www.jstor.org/stable/2999513.

Pedroni, P. (2001a). Fully modified OLS for heterogeneous cointegrated panels. In Badi H. Baltagi, Thomas B. Fomby, R. Carter Hill (ed.) Nonstationary Panels, Panel Cointegration, and Dynamic Panels, Emerald Group Publishing Limited, USA, ISBN: 978-0-76230-688-6 eISBN: 978-1-84950-065-4.

Pedroni, P. (2001b). Fully modified OLS for heterogeneous cointegrated panels. In Nonstationary panels, panel cointegration, and dynamic panels (pp. 93-130). Emerald Group Publishing Limited.

Pedroni, P. (2004). Panel cointegration: asymptotic and finite sample properties of pooled time series tests with an application to the PPP hypothesis. Econometric theory, 20(3), 597-625.

Riti, J. S., Song, D., Shu, Y., \& Kamah, M. (2017). Decoupling CO2 emission and economic growth in China: Is there consistency in estimation results in analyzing environmental Kuznets curve? Journal of Cleaner Production, 166, 1448-1461.

Stern, D. I. (2004). The rise and fall of the environmental Kuznets curve. World development, 32(8), 1419-1439.

Wackernagel, M., \& Rees, W. (1998). Our ecological footprint: reducing human impact on the earth (Vol. 9). New society publishers.

World Bank, 2021. World Bank Open Data Free and open access to global development data. Available: https://data.worldbank.org/

Zilio, M. I. (2012). Curva de Kuznets ambiental: La validez de sus fundamentos en países en desarrollo. Cuadernos de economía. 35: 43-54. 